\title{
PENINGKATAN KUALITAS PENGELOLAAN KELAS MELALUI MANAJEMEN DISPLAY KREATIF BAGI KELOMPOK KERJA GURU SD KECAMATAN PAKAL KOTA SURABAYA
}

\author{
Putri Rachmadyanti, Suprayitno, Ganes Gunansyah \\ Surel: putrirachmadyanti@unesa.ac.id
}

\begin{abstract}
The training aims to build motivation, understanding, and skills of elementary school teachers in designing, creating and managing creative classroom displays. The basis of this training is the number of teachers who do not understand the techniques and forms of management of creative classroom displays. The nature of the theme-based curriculum in 2013 which also allows the teacher to the creation of learning according to the theme, either through the material presented and design classes. The training was conducted by multi-method, allowing participants to get a challenge in following the activities. The results of the activities include various forms of class displays that show participants' enthusiasm in designing and creating creative class displays.
\end{abstract}

Keywords: Classroom Management, Display, Elementary School

\begin{abstract}
ABSTRAK
Pelatihan ini bertujuan untuk membangun motivasi, pemahaman, dan keterampilan guru Sekolah Dasar dalam merancang, membuat dan mengelola display kelas yang kreatif. Hal yang mendasari pelatihan ini yaitu akibat banyaknya guru yang belum memahami teknik dan bentuk pengelolaan display kelas yang kreatif. Hakikat Kurikulum 2013 yang berbasis tema ini juga memungkinkan guru untuk mengkreasikan pembelajaran sesuai tema, baik melalui materi yang disampaikan maupun desain kelas. Pelatihan dilakukan dengan multi metode, sehingga memungkinkan peserta mendapatkan tantangan dalam mengikuti kegiatan. Hasil kegiatan berupa berbagai bentuk display kelas yang menunjukkan atusias peserta dalam merancang dan membuat display kelas yang kreatif.
\end{abstract}

Kata Kunci: Pengelolaan Kelas, Display, Sekolah Dasar

\section{PENDAHULUAN}

Kompetensi professional atau akademis merupakan salah satu kompetensi yang harus dimiliki oleh seorang guru. Hal ini seperti tercantum dalam undang-undang nomor 14 tahun 2005 pasal 10 ayat 1 tentang guru dan dosen. Kompetensi professional ini tak terkecuali juga harus dimilki oleh Guru Sekolah Dasar (SD), sebagai pembangun generasi bangsa sejak usia dini. Guru SD diharapkan mampu merencanakan dan mengelola pembelajaran dengan

Dosen Universitas Negeri Surabaya 
baik sebagai bagian dari penerapan kompetensi professional yang dimiliki. Perencanaan dan pengelolaan pembelajaran pembelajaran meliputi pembuatan perangkat pembelajaran, menyiapkan media dan lingkungan belajar yang efektif untuk siswa agar tercapai tujuan pembelajaran dengan maksimal. Guru biasanya hanya terpaku dengan pembuatan media perangkat pembelajaran, sedangkan faktor lingkungan belajar kurang dikembangkan dengan optimal. Lingkungan belajar yang baik dan efektif diharapkan dapat menciptakan interaksi belajar mengajar yang baik. Guru dituntuttidak hanya pandai atau siap secara materi, metode, media dan evaluasi, namun faktor pengelolaan kelas juga menjadi salah satu faktor penting dalam mengembangkan pembelajaran.

Surabaya sebagai ibukota provinsi Jawa Timur yang memiliki wilayah cukup luas dengan jumlah Sekolah Dasar tahun 2015 tercatat sebanyak 358 sekolah. Kecamatan Pakal merupakan wilayah Kota Surabaya bagian barat dengan karakteristik sebagian besar guruguru SD sudah menerapkan pembelajaran Kurikulum 2013. Guru menerapkan pembelajaran berbasis tema dengan cukup bagus, didukung dengan adanya fasilitas penunjang dari sekolah seperti Laptop, LCD, dan lain-lain. Namun, disisi lain guruguru kurang memperhatikan faktor pengelolaan kelas. Berdasarkan wawancara dengan beberapa guru SD di Kecamatan Pakal, diperoleh hasil bahwa selama pembelajaran formasi bangku siswa sering monoton, siswa jarang bahkan tidak pernah berpindah-pindah tempat saat diskusi maupun belajar individu, dan guru malas mengelola pajangan atau display kelas. Hal ini dapat dilihat dari guru yang membiarkan dinding kelas kosong atau kalaupun ada gambar atau media, biasanya gambar tersebut dipasang bertahun-tahun. Hasil karya siswa dikumpulkan dan ditumpuk di meja paling belakang. Lemari yang ada di kelas diisi dengan buku- buku yang sudah rusak dan tidak pernah digunakan selama pembelajaran.

Secara teori, ruang kelas merupakan suatu ruangan dalam bangunan sekolah, yang berfungsi sebagai tempat untuk bertatap muka antara guru dan siswa dalam pembelajaran. Mebeler dalam ruangan kelas ini terdiri dari meja siswa, meja guru, lemari, papan tulis (black board atau white board), serta aksesoris ruang lainnya yang lazim disebut display kelas. Lingkungan fisik dalam ruangan kelas ini dapat menjadikan suasana belajar menjadi aktif. Chatib (2013: 33) mengungkapkan ada dua hal sederhana yang perlu diperhatikan agar ruang kelas itu menyenangkan dan tidak menjadi penjara bagi siswa, yaitu: 1) menyusun barang-barang pelelngkap yang ada di dalam kelas layaknya seorang desainer interior; 2) 
membuat display kelas. Hal senada juga diungkapkan oleh Silberman (2009: 15) yang mengungkapkan bahwa dekorasi interior dari belajar aktif adalah menyenangkan dan menantang bagi siswa. Walaupun pembelajaran tidak selalu dilakukan di luar kelas, umumnya banyak dilakukan di dalam kelas. Oleh sebab itu, ruang kelas hendaknya menjadi tempat yang menyenangkan karena berfungsi sebagai tempat belajar bagi guru dan siswa.

Masalah-masalah desain kelas ini terkadang diremehan karena guru menganggap yang terpenting adalah penyampaian materi. Display kelas atau lazim disebut pajangan kelas berperan penting dalam menciptakan suasana belajar yang kondusif. Dananjaya (2010: 265) mengungkapkan bahwa pengaturan kelas dapat mendorong motivasi siswa dalam pembelajaran. Selain itu, Arends (2013: 134) berpendapat bahwa susunan siswa, meja, kursi, tidak hanya membantu menentukan pola komunikasi kelas dan hubungan interpersonal antara guru dan siswa, melainkan mempengaruhi berbagai keputusan harian yang harus dibuat guru terkait dengan pengelolaan dan penggunaan sumber-sumber belajar. Eversten dalam Dananjaya (2010) yang melakukan riset tahun 2006 mengungkapkan tentang pengaturan ruang kelas yang baik adalah siswa terbebas dari hambatan dalam melakukan pergerakan. Makna tersirat dari riset ini adalah kondisikan ruang kelas fleksibel untuk siswa dalam belajar dan mencari literatur guna mengkonstruk pengetahuan. Guru diharapkan dapat menata bahan-bahan pelajaran dan perlengkapan siswa yang sering digunakan dapat dicapai dengan mudah. Siswa dipastikan dapat leluasa bergerak dan melihat materi pembelajaran tanpa hambatan.

Kelas yang berpusat pada siswa mengkondiiskan siswa dapat mengkonstruksi pengetahuan melalui interaksi dengan sesamanya. Seorang guru yang efektif melihat ruang kelas sebagai suatu bentuk kehidupan yang bergerak dan mengamati semua gerakan. Untuk itu, guru membutuhkan perhatian langsung dan memotivasi siswa untuk berpasrtisipasi aktif serta memberikan kesempatan yang cukup bagi siswa untuk mengembangkan diri. Pengaturan bangku siswa yang tidak monoton membuat siswa mendapatkan pengalamanpengalaman baru dalam belajar. Faktor kesibukan, kurangnya kemampuan dan keterampilan menjadi alasan guru untuk malas mengelola display kelas. Padahal saat ini guru-guru dituntut dapat melaksanakan pembelajaran yang kreatif dan menyenangkan. Kurikulum 2013 yang berbasis tema memungkinkan guru untuk mengkreasikan pembelajaran sesuai tema, baik melalui materi yang disampaikan maupun desain kelas. 
Berdasarkan masalah yang ada di SD terkait dengan pegelolaan kelas maka disusunlah sebuah kegiatan pelatihan manajemen display kelas bagi guru SD di Kecamatan Lakarsantri Kota Surabaya Pelatihan ini diharapkan dapat memberikan motivasi bagi guru-guru SD untuk meningkatkan kualitas pembelajaran melalui manajemen display kelas yang kreatif. Hal ini mengingat suasana dan desain ruang kelas secara tidak langsung memberikan pengaruh yang luar biasa dalam kefektifan penyampaian materi dan motivasi belajar siswa. Alternatif kegiatan ini dimaksudkan untuk membantu memberikan solusi permasalahan pembelajaran di SD dan memberikan kontribusi yang positif untuk kualitas pendidikan dasar di Kota Surabaya. .

\section{METODE PENELITIAN}

Target atau sasaran pelatihan manajemen display kelas kreatif ini adalah guru-guru yang tergabung ke dalam Kelompok Kerja Guru (KKG) SD Kecamatan Pakal Kota Surabaya. Daerah ini dipilih mengingat banyak kelas yang belum mengelolan display kelas dengan bagus dan efektif sesuai dengan berlakunya kurikulum 2013 yang berbasis tema. Syarat mengikuti pelatihan ini sangat mudah, yaitu guru-guru yang memiliki motivasi untuk meningkatkan kualitas pembelajaran dan meningkatkan kompetensi profesional sebagai guru. Setelah kegiatan pelatihan ini diharapkan guru-guru SD di Pakal memiliki pengetahuan dan pemahaman mengenai bagaimana mengelola, merancang, dan membuat display kelas yang kreatif dan menarik.

Jumlah Sekolah Dasar yang tergabung dalam KKG Kecamatan Pakal sebanyak 15 sekolah. Dalam pelatihan manajemen display kelas ini diikuti oleh 45 orang guru SD dari sekolah-sekolah tersebut. Kegiatan Pengabdian Kepada Masayarakt ini dilaksanakan pada 1 Oktober 2016 berempat di SD Babat Jerawat 2 Kecamatan Pakal. Adapun gambaran kegiatan yang dilakukan di lapangan berorientasi pada hal-hal sebagai berikut.

1. Pelatihan berorientasi pada produk akhir berupa ketrampilan merancang dan membuat display kreatif

2. Pelatihan dilakukan dengan multi metode, sehingga memungkinkan peserta mendapatkan tantangan dalam mengikuti kegiatan pelatihan.

3. Pelatihan dan pendampingan oleh tim Dosen PGSD UNESA, sehingga berbagai pertanyaan dan ketidakpahaman peserta mengenai materi pelatihan akan dapat diuraikan dengan lebih mudah dan jelas.

Ada tiga faktor utama yang diperhatikan dalam metode pelaksanaan kegiatan pengabdian kepada masyarakat ini, yaitu: 
1. Pegelolaan Pelatihan

Pelaksanaan pelatihan akan memperhatikan tingkat kenyaman peserta, baik secara fisik, psikis maupun sosial.

2. Penyampaian Materi

Penyampaian materi akan dilakukan dengan menggunakan multimedia yang diselingi dengan diskusi kelompok, brainstorming, dan unjuk kerja.

3. Perumusan Strategi Pelatihan

Penyusunan rumusan strategi pelatihan manajemen display kelas disesuaikan dengan konteks pembelajaran yang kreatif dan menyenangkan.

Jurusan PGSD UNESA sebagai salah satu lembaga pendidikan yang menjadi wadah pencetak calon guru guru SD memiliki peran penting dalam mengembangkan profesi keguruan. Adanya pelatihan manajemen display kelas ini menjadi bentuk kontribusi jurusan PGSD dalam membantu mencetak guruguru yang professional. Demi kelancarandan ketercapaian tujuan tersebut maka telah dibentuk sebuah tim yang terdiri dari beberapa tenaga ahli pada bidangnya yang telah disesuaikan dengan kebutuhan pelatihan ini. Berdasarkan bidang keahlian masing-masing anggota tim, maka lingkup tugas dan tanggung jawab dalam menyelesaikan pekerjaan ini dipaparkan sebagai berikut, menyusun handout, memberikan pemaparan dan diskusi mengenai pengelolaan kelas di Sekolah Dasar dan manajemen display kelas yang baik, menjelaskan dan mendiskusikan secara detail manajemen display kelas yang efektif dan menarik melalui skenario rancangan display kelas serta memberikan pendampingan pembuatan display kelas yang kreatif untuk kelas di Sekolah Dasar.

HASIL DAN PEMBAHASAN

Kegiatan pengabdian masyarakat ini didahului dengan adanya curah gagasan dan pengalaman guru-guru (peserta pelatihan) saat mengelola kelas. Berdasarkan kegiatan curah gagasan tersebut dapat diketahui beberapa kendala yang dialami oleh peserta terkait dengan pengelolaan display kelas antara lain : (1) secara konseptual guru belum mengetahui secara spesifik tentang teknik memajang karya siswa; (2) secara konseptal dan praksis, peserta belum mengetahui tentang jenis jenis display kelas; (3) faktor kurangnya motivasi dalam menata hasil karya siswa; (4) peserta lebih fokus pada pembelajaran dan evaluasi, sedangkan untuk memajang karya siswa kurang diperhatikan.

Selanjutnya berdasarkan kendala tersebut, pendampingan diarahkan untuk mengakomodir serta menawarkan alternatif penyelesaian melalui kegiatan pendampingan penerapan secara praktis cara menyusun dan mengembangkan display kelas yang kreatif untuk Sekolah Dasar. Teknik pelaksanaan 
kegiatan lebih ditekankan pada kegiatan pendampingan dibanding penyampaian secara ceramah/ ekspositori. Proporsi kegiatan $70 \%$ pendampingan, sementara $30 \%$ penyampian teori. Teknik ini dipandang lebih efektif mengingat para guru di SD Pakal Surabaya membutuhkan contoh praktis dan konkrit mengenai cara menerjemahkan dan menghadirkan praktek pembelajaran yang baik di SD.

Selesai penyajian materi, kegiatan dilanjutkan dengan membentuk peserta menjadi beberapa kelompok, tiap kelompok terdiri dari 5 orang. Kemudian masing-masing kelompok diberikan alat dan bahan untuk merancang dan membuat contoh display kelas, seluruh peserta menyepakati untuk membuat papan buletin. Fasilitator memberikan kebebasan pada masing- masing kelompok untuk membuat kreasi papan buletin dan dibantu dengan tayangan dan contoh riil dari papan buletin yang sudah jadi dan siap digunakan di kelas.

Masing-masing kelompok diberikan alat dan bahan seperti papan, berbagai macam jenis kertas, gunting, lem, dan lain-lain yang merupakan bahan utama membuat papan buletin. Anggota kelompok menentukan jenis papan buletin yang akan dibuat kemudian bekerja sama merancang dan membuat appan bulletin. Selesai praktek pembuatan papan buletin sebagai salah satu contoh display kelas, masing-masing kelompok mempresentasikan produk yang telah dibuat bersama kelompok. Fasilitator dan peserta pelatihan yang lain memberikan saran dan masukan guna mewujudkan display kelas yang kreatif. Upaya ini dimaksudkan sebagai bentuk RTL (Rencana Tindak Lanjut) agar guru selalu termotivasi untuk tidak cepat merasa puas melainkan termotivasi untuk senantiasa melakukan perbaikan dan penyempurnaan.

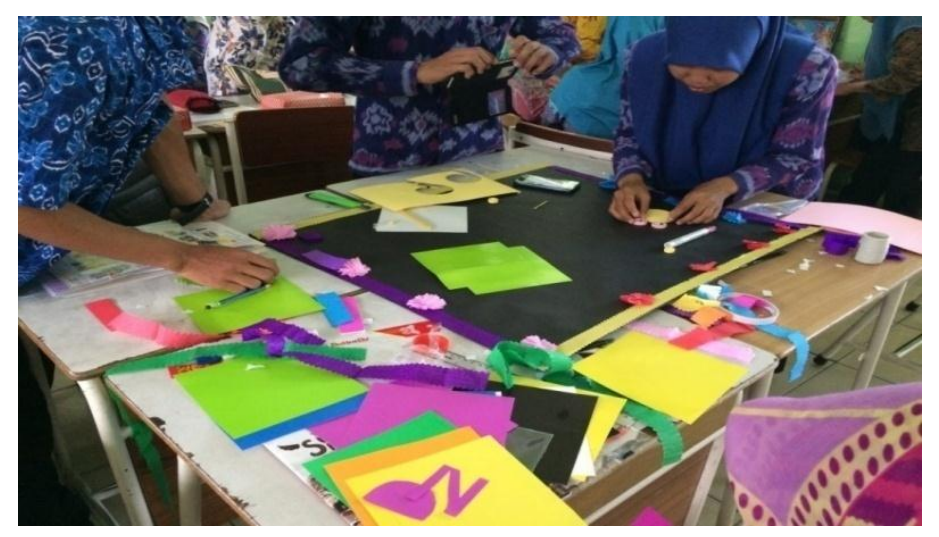

Gambar 1. Peserta bekerja sama membuat salah satu display kelas (papan buletin) 
Adapun hal-hal yang menjadi faktor pendorong dan penghambat kegiatan ini adalah (1) menariknya materi yang disajikan yakni tentang pengelolaan display kelas karena merupakan hal yang baru bagi sebagian guru, 2) Keingintahuan peserta yang cukup besar dari para peserta terhadap materi yang diberikan, 3) Praktek langung pembuatan salah satu display kelas (papan buletin) membuat peserta antusias dan materi yang disajikan lebih bermakna. Sedangkan yang menjadi faktor penghambat dalam kegiatan ini adalah: waktu pelaksanaan dirasa kurang, sehingga peserta hanya memiliki pengalaman membuat satu jenis papan display dari 4 jenis papan buletin. Tim juga merasa kesulitan dalam masalah waktu ketika akan mengadakan bimbingan secara berkelanjutan.
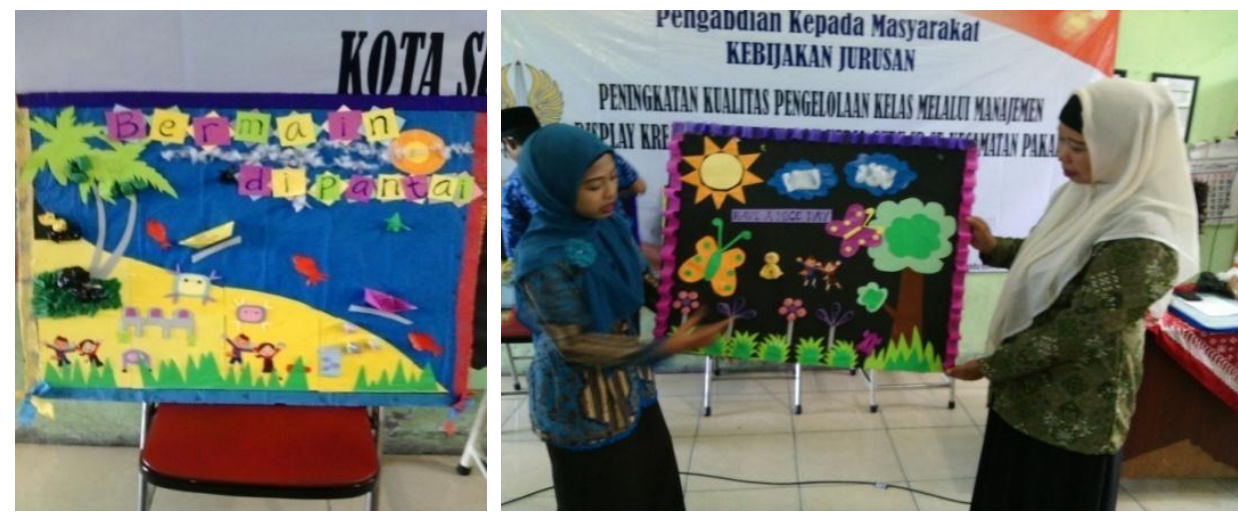

Gambar 2. Hasil pembuatan display (papan buletin)

Adapun hasil dari angket respon yang diberikan kepada peserta setelah kegiatan yaitu $80 \%$ peserta memahami materi yang disampaikan, $85 \%$ menyatakan bimbingan yang diberikan oleh tim instruktur juga mudah dimengerti, $90 \%$ peserta menyatakan puas dengan metode yang diberikan oleh tim instruktur. Kritik dan saran yang diberikan oleh peserta sebagian besar tentang waktu pelaksanaan pelatihan yang dirasa kurang karena peserta merasa cukup antusias dengan materi yang diberikan, dan merupakan hal baru bagi peserta. Semoga kritik dan saran yang diberikan peserta dapat dipertimbangkan dengan baik untuk kegiatan pengabdian kepada masyarakat tahun mendatang.

Dari capaian kemajuan pelaksanaan PKM sebagaimana yang dipaparkan pada uraian sebelumnya, maka kegiatan yang belum dilaksanakan dan direncanakan akan dicapai pada tahapan berikutnya adalah

1. Menerapkan materi pelatihan ke dalam real class yang dilaksanakan praktikan (peserta) di kelas tempatnya mengajar. Kegiatan tersebut dilaksanakan 
dengan didampingi oleh fasilitator sebagai observer/pengamat.

2. Melaksanakan pendampingan secara informal bila sewaktuwaktu diperlukan dan diminta oleh pihak sekolah

3. Menyusun makalah untuk diseminarkan pada seminar nasional atau forum ilmiah lainnya.

\section{SIMPULAN}

Berdasarkan capaian kemajuan pelaksanaan PKM ini dapat disimpulkan bahwa penerapan pembelajaran yang baik di SD ini sangat dibutuhkan oleh para guru yang sedang berupaya meningkatkan kapasitas dan kapabilitasnya dalam meningkatkan mutu pembelajaran, khsuusnya dalam hal pengelolaan display kelas. Selain itu, praktek ini juga sangat relevan dengan tuntutan kurikulum 2013 nasional yang saat ini sedang dijalankan khususnya di Surabaya. Hasil pelatihan menunjukkan bahwa guru mulai memahami teknik merancang dan membuat display kelas kreatif bagi anak Sekolah Dasar. Berbagai muatan unit materi yang sudah disajikan selama pelatihan juga dapat diaplikasikan ke dalam pembelajaran dan manajemen pengelolaan kelas (real class).

Adapun saran yang diberikan yaitu guna memantau sejauhmana materi pelatihan sudah diterapkan dengan baik, maka diperlukan kaji ulang sejauhmana keberhasilan dicapai dan kendala-kendala dapat diatasi. Dalam jangka panjang, pelatihan ini dapat diperluas dalam skala KKG yang dilaksanakan secara berkelanjutan. Baik sekolah maupun perguruan tinggi, dalam hal ini jurusan PGSD FIP Unesa dapat saling memperoleh manfaat. Sinergi ini diharapkan menjadi budaya baik yang dapat berlanjut dalam berbagai kesempatan.

\section{DAFTAR RUJUKAN}

Arends, Richard I. 2013. Learning to Teach. Jakarta: Salemba Humanika.

Chatib, Munif. 2015. Kelasnya Manusia: Memaksimalkan Fungsi Otak Belajar dengan Manajemen Display Kelas. Bandung: Mizan Media Utama.

Dananjaya, Utomo. 2010. Media Pembelajaran Aktif. Bandung: Nuansa.

Silberman, Mel. 2009. Active Learning: $101 \quad$ Strategi Pembelajaran Aktif. Yogyakarta: Pustaka Insan Madani. 